\title{
Ethics in Organizational Communication
}

\author{
Muhammad Alfikri, S.Sos, M.Si \\ Lecturer at Ushuluddin Faculty, State Islamic University (UINSU/IAIN), Medan, Indonesia
}

\begin{abstract}
Organization is the social entity which is consciously coordinated with a relatively identifiable boundaries, and works on a relatively continuous basis to achieve a common goal. Social entity, it means that, the unity made up by people or groups of people interacting each other. Communication is something that must be used in organizations, institutions and companies. The aim of communication within the company invites all members of the company cares for interaction with other members outsiders.
\end{abstract}

Keywords: ethics; organizational communication; top management

\section{INTRODUCTION}

The importance of communication for humans cannot be denied, as well asan organization. By using a good communication, an organization could walk smoothly and successfully and vice versa,lack or absence of communication, organizations can raise many problems.Effective communication is essential for all organizations. The organization's leaders and communicators in the organization need to understandand enhance their communication skills. Therefore,communication and organizational success are closely related, repair organizational communication means improving the organization. An ideal organization is formed from universal elements which can be foundand used to transform an organization. The main goal in studying the communication is to improve the organization.

Organization is the social entity which isconsciously coordinated with a relatively identifiable boundaries, and works on a relatively continuous basis to achieve a common goal.Social entity, it means that, the unity made up by people or groups of people interacting each other. Communication is something that must beused in organizations, institutions and companies. The aimof communication within the company invites all members of the company cares forinteraction with other members outsiders. Therefore,communication activity has an important role in expeditingthe performance of the company's activities, internally or externally, to achieve goalseffectively and efficiently.

\section{METHODOLOGY}

\section{Definition of Ethics}

In the modern society life, even in this postmodern era,each individual member of the community in his social interaction with another community or environment, seems likely to getfree, flexible, and open. It does not mean there is no restriction atall, because when someone makes a mistake of offendingor violate to another person, then such personwill face legal sanctions based on the demands of the people. It is of course different from the situation in the past, which tends to be rigid and closed, becausedaily life at the past is limited by various normative orvarious restrictions that must be obeyed by custom.

It shows that in everyday life,every member of society will be faced with the limitations valueof normative, which applies to any given situation and tends to change fromtime to time. The boundaries of normative values when interacting withsociety and the environment is referred to ethical values. Ineveryday life, it is common to use the words of ethics and morals.

These terms are often considered the same meaning, so sometimes they are used overlapping and ambiguous. It is always happenbecause basically these terms are equally related tohuman actions and 
assessment of these actions, such as good or bad.But actually, these termshave a different point of viewin human actions.

This term viewed from language, is derived from the Greek,ieethos (singular), which means a place to stay, meadows,cage, habits, customs, character, feelings, attitudes and ways of thinking. Pluralof the word ethicsis ta etha, which means customs. In this case, the meaning of the word ethics is samewith morals. Moral is derived from Latin word,mos (singular), or mores (plural) which means customs, habits, character, temperament, character and way of life.So in this case, ethicsis a pattern of behavior or habits which are good and can be received bymany people or specific organizations.

According to K. Bertens, there are three approaches that can be done inunderstand the context of ethics, namely descriptive ethics, normative ethics and meta-ethics:

\section{Descriptive Ethics}

Descriptive ethics is a morality contained in a certain person in certain culture and in a certain period of history, and so on.Because, descriptive ethics is only a portray, which does not give an assessment.

\section{Normative Ethics}

Normative ethics is an important part of ethics and the most interesting moral issues. Normative ethics determines whether good or not the behavior or moral assumptions. Normative ethics aims to formulate ethical principles that canaccounted for in a rational way and can be used in practice.

\section{Meta-ethics}

Meta-ethics studies the specific logic of ethical. Meta-ethicsfocuses its attention to the specific meaning of the ethical language. British philosopher, Geoge Moore (1873-1958), in his book, writes meta-ethics withhighlights for comparing one sentence with other sentences.

According to Ricky W. Griffin and Ronald J. Ebert, ethics is the action of right and wrong, orgood and bad, affecting other things. The valueof individual and personal moral as well as social context determines whether aspecific behavior is regarded as conduct that is ethical or unethical. Ethical behavioris the appropriate behavior to social norms accepted in connection with the actions of right and good. It determines the quality of the individual. While unethical behavioris thecontrary behavior to the norm in society.

Based on the above explanation, it can be understood that ethics is a referencewhich is always used by individuals or groups as a guide incarry out daily activities, so that activities do not harmanother person. Thus, ethics and morals are veryclosely in terms of meaning.But in practice, the term of ethics is used forreviewing people's action.

Based on Islamic point of view, ethics is known as morals that is characters, temperament or behavior. In daily interactions, moral needs to be considered and taken care of, because it will makesomething organized. As affirmed by IbnMiskawayh, the goal of morals is to reach al-Sa 'adah which means happiness,prosperity,success, perfection and pleasure.

AlQur'an orders someone to begentle and polite when he talks to other people. Furthermore, Al Qur'an requires to someone to be polite in every way when speaking. God commands to Muslims to always be gentle and it contains in Surah Ali Imran verse 159. Meaning:

"Then due to the grace of God to Whom you apply gentle towards them. If you were to get tough again be rude, they would distance themselves from the round about. Therefore forgive them and ask forgiveness for them and discuss the proble with them. Then if you have been determined, then put thy trust upon Allah. For Allah loves those who put their trust upon Him.

The ethic of the organization can be used to set and as a benchmark in describing anything that is ethical to be done and it is not ethical in the organization. Hunt et.al also claimed that the value of ethicalorganization is a degree of understanding of how the organizationbehave and act in the face of ethical issues. Thisatterincludes the perceived level: 
a. How the management in assessing workersact against ethical issues within the organization.

b. How works consider that the management pays attention to ethical issues inorganization and

c. How workers judge that ethical behavior (orunethical) will be given a reward (penalty) in organization.

Trust is the main capital in doing business. Therefore, some companies develop and disseminate standards and ethical valuesof employees. With the understanding and application of business ethics, it is expected toincreasing the professionalism of all levels of their employees. Generally,grains core code of conduct several organizations, among others:

a. Compliance, ie the observance of laws and regulationsapply.

b. Integrity, that is not abuse of office and authority forpersonal or family interests, maintain the good name of the organization and security and so on.

c. Ethical, that no misconduct/speculative action.

d. Harmonization in workingenvironment, is to maintain and foster harmonyenvironment and fair competition.

e. Competence means constantly improve the knowledge and insight,to follow the development of modem organization.

Most companies have its own ethical code to encourageemployees behave ethically. But the code of conduct is not enoughso that the company's owners and managers must set high ethical standards in order to create an effective control environment and efficient.

According to Griffin and Ebert, there are two most common approaches to forming top management commitment to ethical business practices, namely:

a. Implement a written code of conduct. Many companies write code of conductformally expressed their desire to dobusiness with ethical behavior. The number of companies increaserapidly within the last three decades, and nowalmost all large corporations have a written code of conduct.

b. Enforce ethics program. Many examples suggest thatethical response can be learned by experience.

Some efforts to avoid a violation of the ethics inorganization, then according to Alvin A. Arens, there are several ethical principlemust be maintained for every member of the organization:

\section{a. Responsibilities}

In carrying out the responsibilities as professionals, membersorganizations should implement professional judgment and moral sensitivein all their activities.

\section{b.PublicInterest}

The members of the organization must accept the obligation to actin such a way so as to serve the public interest, as well as showingcommitment and professionalism.

\section{c. Integrity}

To maintain and broaden public confidence, themembers of the organization must carry out all their professional responsibilitieswith a high degree of integrity.

\section{d. Objectivity and Independence}

Each member organization shall maintain objectivity and freeof conflict of interest in carrying out their professional responsibilities.

\section{e. Scrupulosity}

Members of the organization must maintain a technical and ethical standards of the profession,continue to strive to improve the competence and quality of services that it provides, as well as carrying out a professional responsibility and in accordance with his best ability.

\section{f.Scope and Nature of Services}


Members of the organization who practiced for the public should pay attention the principles of the code of professional conduct in determining the scope andnature of the services to be provided.

\section{DISCUSSION}

\section{Strengthening Basic Principles of Ethical Organizations}

Building organizational ethics is certainly not easy, because it mustbe supported by all parties in an organization or institution. The success of the development of an ethical behavior and organizational culture will effectively support the implementation of cultural values. Some factorsto encourage the creation of good ethics or ethical behavior in organization namely:

Firstly, the influence of culturalorganization. Organizational culture is a system of shared meaning held bymembers that distinguishes the organization from other organizations.

Secondly, the political conditions. The political situation is a series of right principles,state, street, way or tool to be used to achieve the goal.

The achievement is influenced by the behaviors of individuals or groupscontained within a single organization. Third, the global economy, as it pertainsbehavior and human action to meetthe needs of lifevary and evolve with existing resources through the choicesof production, consumption. In addition to these three factors, it can be identified that strengthening ethicsorganization which can be done in some ways, namely:

\section{Commitment of Top Management Organization}

Top managers should certainly provide role models and a strong willto build a strong culture within the organization he leads.The role of moral/character of a leader and his commitment.In an organizational unit, especially a large organizational units, frommanagement is needed two things: the moral commitment and openness in communication. Both of these can bring hope emergence. Strong ethical behavior, because many employees who do not like the actof leaderswhich have less moral and less open communication.

\section{Conducive Environment Organization}

Many research results provide an indication of wrongdoing such as corruption within an organization due to lack of positive awareness of employees against the wrongdoings. The low awareness and low moral will fertilize cheating measures that will eventually break evencan destroy the organization. Factors such indifference betweencaused by:

a. Top management is less concerned about the penalties and rewards.

b. Negative feedback is perceived by unscrupulous employeesor a good mentality and placement unfair or does not match the capabilities of employees.

c. The growing sense of indifference would in the organization

d. Leaders more authoritarian and less appreciated employees.

e. The low loyalty and a sense of organization.

f. Irrational budget and coercion achievement of targets irrational.

g. Lack of employee training and lack of promotion opportunities.

h. Unclear accountability organizations.

i. The lack of communication and methods in organization.

The personnel in organization should assist increating instruments that leads to the culture of the organization andsupportive environment. Unit manager of Human Resourceshas aresponsibility for the implementation of the program, initiative andconsistent with management strategy.

\section{Recruitment and Promotion Officer}

Each member in organization would have the values of honesty, integrity and personal ethics code. Therefore, in prevention of fraud, then the organization must havean effective policies in recruitment and promotion of employees. Withpay attention to the process of recruitment and good promotion, then an organization 
will be able to recruit members who have a high level of honesty,particularly for positions that require the highest level.

\section{Good Climate Organizational Communication}

Communication is a matter that cannot be avoided by humans. Communication is at the core of all social relations. If someone hashold a permanent relationship, then the communication system they do will determine whether the system is tightened or unite them.

\section{Training Management of Sustainable Organizations}

New employees should be trained in the organization's values andimplementation of the standards at the time of recruitment. Training should be an explicit which can adopt the expectations of all employees. Included in this concerns the question of how to communicate the issuesfacing members of the organization. There should be certainty of senior managementas the expectations of employees and responsibilities of the communication.

Commitment to ongoing education and awareness for employees onissues relating to ethics and anticorruption pushes the establishment of a reliable organization. Therefore, sustainable education and training programsmust be made for the benefit of the organization and relevant with the wishes of employees.

\section{Enforcement Discipline}

Discipline is an important key in getting succeed. Discipline must be upheld together by all elements of the organization. Because if it is only done by a group of people, then sooner or later,the others will also be affected.

\section{EFFECT OF ORGANIZATIONAL COMMUNICATION ETHICS}

Redding and Sanborn, as quoted Muhammad Ami, saidthat communication organization is sending and receiving information incomplex organizations; internal communicationinternal, human relations, union relations manager, downward communicationsor communication from superiors to subordinates, upward communication or communication of subordinates to superiors, horizontal communication orcommunication of those who have same level/ levels within the organization,communication skills and speaking, listening, writing and communication evaluation program.

\section{CONCLUSION}

Ethics is a procedure of moral in doing good, especially inorganization. The ethical values in an organization set forth inrules or provisions of the law, written or unwritten. This rule isarranged so that everyone is able to act or behave well wheninteract with others in the organization. Ethics serve ascode of conduct or pattern of behavior on any individual or member of an organization. In the organization, ethics has the most important role and has a high value. This is to monitor the state's inside organizations in order to create the atmosphere of the organization that is disciplined, decisive and professionalandharmony in the organization withall members. 


\section{REFERENCES}

[1] Agoes, Sutrisnodan I CenikArdana. EtikaBisnisdanProfesi. Jakarta: SalembaEmpat, 2009.

[2] Amir, Mafri. EtikaKomunikasi Massa dalamPandangan Islam. Jakarta: Logos, 1999.

[3] Arens, Alvin A dan James K. Loebbecke. Auditing: an Integrated Approach.Prentice Hall, 1997.

[4] _ Auditing danJasa Assurance. Jakarta: Erlangga, 2006.

[5] Bertens, K. Etika. Jakarta: PT. GramediaPustakaUtama, 2011.Griffin, Ricky W dan Ronald J. Ebert. Business. Texas: Prentice Hall, 2006. Goldhaber, Gerald M. Organizational Communication. State University of NewYork: Wm.C. Brown Publishers, 1986.

[6] Hunt, S.D. et.al. "Corporate Ethical Values and Organizational Commitment inMarketing” dalamournal of MarketingScience, No 53. tahun 1989

[7] Jamil, Alwiyah. PengaruhEtikaKerja Islam TerhadapSikapPadaPeruabahanOrganisasi: KomitmenOrganisasiSebagai Mediator. .Semarang: TesisFakultasEkonomiUniversitasDiponegoro, 2007.

[8] Masmuh, Abdullah. KomunikasiOrganisasiDalamPerspektifTeoridanPraktekMalang: UMMPress, 2010.

[9] Miskawaih, Ibnu. MenujuKesempurnaanAkhlak, teri. HelmiHidayat. Bandung:Mizan, 1994.

[10] Muhammad, Ami. KomunikasiOrganisasi. Jakarta: BumiAksara, 2005. Rudito,

BambangdanMeliaFamiola. EtikaBisnis\&TanggungJawabSosialPerusahaan di Indonesia. Bandung: RekayasaSains, 2007.

[11] Schein, Edgar H. Organizational Culture and Leadership. San Francisco: JosseyBass, 1992. 